http://nv.nltu.edu.ua

\title{
МОДЕЛЮВАННЯ РОЗМІРНО-ЯКІСНОЇ СТРУКТУРИ СТОВБУРІВ ДУБА ЗВИЧАЙНОГО ЗА ЄВРОПЕЙСЬКИМИ СТАНДАРТАМИ
}

Розглянуто проблеми, які виникли внаслідок набуття чинності нових стандартів на продукцію лісозаготівель. Невідповідність нормативно-інформаційної бази для таксації лісосік новим вимогам призводить до значних недоліків у плануванні виробничої діяльності лісогосподарських підприємств. Дослідження виконано на підставі дослідного матеріалу, зібраного в дубових насадженнях Придніпровського Правобережного Лісостепу на тимчасових пробних площах. Проаналізовано розподіл об'єму ділових стовбурів дуба звичайного (Quercus robur L.) на якісні категорії деревини залежно від діаметра, висоти та об'єму. Найбільш тісну лінійну залежність виявлено для абсолютних значень якісних категорій деревини від об'єму стовбура в корі. Між іншими біометричними показниками стовбура лінійна залежність відсутня або менш значуща на 5 \%-му рівні. Завдяки аналізу модельовано вихід якісних категорій деревини залежно від об'єму стовбура на підставі степеневого рівняння. Пошук параметрів рівнянь виконано у MS Excel. Систематична похибка математичних моделей виходу ділової деревини виявилася близькою до нуля (1,0\%), дров та відходів - у допустимих межах $(5,1$ та 8,0 \%), що дало змогу прийняти їх для розробки відповідних таблиць. Опрацьовані таблиці дають змогу за новими стандартами прогнозувати розподіл об'єму ділових стовбурів дуба зі стандартною похибкою $0,063-0,118$ м². Для отримання даних розподілу об'єму ділової деревини за класами розмірів, передбачених ДСТУ 1315-1-2011, розроблено в системі R алгоритм умовного розкряжування модельних дерев. Він оснований на апроксимації твірної поверхні стовбура за допомогою математичної моделі твірної А. Kozak (1988). На підставі одержаного розподілу об'єму ділової деревини за класами діаметрів досліджено його залежність від біометричних показників стовбурів. Практично для всіх розмірних категорій деревини виявлено нелінійний зв'язок. Узагальнення розмірної структури ділової деревини проведено за методикою, яка базується на дослідженні закономірностей розподілу об'єму за класами розмірів у відносних величинах. Виявлено тісну залежність відносних величин розмірної структури від діаметра модельних дерев на висоті 1,3 м. Незначна систематична похибка отриманих математичних моделей розподілу ділової деревини (-1,1-0,9 \%) дала змогу прийняти їх для складання об'ємних таблиць. Розроблені за новими стандартами таблиці забезпечують прогнозування розподілу об'єму ділової деревини ділових стовбурів дуба за класами розмірів залежно від серединного діаметра лісоматеріалів без кори.

Ключові слова: стандарти круглих лісоматеріалів; категорії технічної придатності стовбурів; розмірно-якісна структура об'єму стовбурів; математичні моделі розподілу деревини.

Вступ. Як відомо, з 01.01.2019 р. в Україні втратили чинність стандарти, які стосуються продукції лісозаготівель. Так, з відміною ГОСТ 9462-88 (Lesomaterialy kruglyye, 1988) та ГОСТ 2708-75 (Lesomaterialy kruglyye, 1975), втратили чинність національні примітки в ДСТУ 4020-2-2001 (Lisomaterialy kruhli ta pyliani, 2001) та ДСТУ ЕN 1315-1-2001 (Lisomaterialy kruhli lystiani, 2002), які сьогодні регламентують обмір, визначення об'ємів та класифікацію за розмірами лісоматеріалів круглих тільки за серединним діаметром. Набув чинності ДСТУ ЕN 1316-1:2018 та розроблені на їх основі ТУУ-00994207-003:2018 (Zbirnyk tekhnichnykh umov, 2019), які встановлюють вимоги та правила сортування лісоматеріалів дуба та інших порід за якістю. Замість відмінених ТУУ 56.196-95 (Derevina drov'yana, 1995) та ГОСТ 3243-88 (Drova, 1989) уведено ТУУ-00994207005:2018 (Zbirnyk tekhnichnykh umov, 2019), які розроблені з урахуванням основних нормативних положень EN ISO 17225-5:2014 та класифікують дров'яну дереви- ну промислового та непромислового використання за якістю та розмірами.

Одним із важливих питань щодо планування виробничої діяльності лісогосподарських підприємств є структура лісосічного фонду, тобто розподіл деревини на ділову, дров'яну та відходи, а ділової за класами розмірів та якості. У сучасних умовах частина напрацьової роками нормативної бази, яка давала змогу вирішувати зазначені завдання, втратила свою актуальність. Це стосується таблиць розподілу об'єму стовбурів за розмірно-якісними категоріями, сортиментних і товарних таблиць, які розроблені на підставі відмінених стандартів. Одним із напрямів наших досліджень $є$ розроблення зазначених регіональних нормативів на підставі нових стандартів, гармонізованих з європейськими вимогами.

Мета дослідження - визначити закономірності виходу ділової деревини, дров та відходів 3 ділових стовбурів дуба; дослідити розподіл ділової частини стовбурів за класами розмірів; розробити математичні моделі

\section{Інформація про авторів:}

Биченко Володимир Борисович, здобувач, кафедра таксації лісу та лісового менеджменту. Email: vladimirbb@i.ua

Цитування за ДСТУ: Биченко В. Б. Моделювання розмірно-якісної структури стовбурів дуба звичайного за європейськими стандартами. Науковий вісник НлТУ України. 2019, т. 29, № 7. С. 90-95.

Citation APA: Bychenko, V. B. (2019). Modeling of Size and Quality Structure of Common Oak Tree Stem in Compliance with European Standards. Scientific Bulletin of UNFU, 29(7), 90-95. https://doi.org/10.15421/40290718 
цих залежностей та на їх основі скласти відповідні таблиці розподілу.

Матеріал і методи дослідження. Дослідні дані отримали за результатами обміру 102-х ділових модельних дерев дуба (МД) на 17-ти тимчасових пробних площах у пристиглих, стиглих та перестиглих дубових деревостанах Придніпровського Правобережного Лісостепу. Варто зауважити, що в Україні сьогодні немає вимог чи методик класифікації стовбурів за категоріями технічної придатності (ділові, напівділові, дров'яні) згідно 3 новими стандартами на лісоматеріали. 3 огляду на це в дослідженні за ділові вважали дерева, з окоренкової частини стовбура яких можливо заготовити діловий сортимент категорій А, В, С (за ТУУ-00994207003:2018) (Zbirnyk tekhnichnykh umov, 2019) довжиною не менше ніж 6,5 м (відповідно до методичних вказівок із відведення лісосік) (Metodychni vkazivky, 2013).

Для дослідження розмірно-якісної структури об'єму стовбурів зрубаних дерев за зовнішніми ознаками визначали відстань від окоренка до точок зміни класів якості ділових лісоматеріалів, або переходу ділової деревини в категорію дров'яної деревини та навпаки. Класифікацію відрізків за якістю проводили одночасно на підставі нормативів, які діяли до 2019 р. (надалі у статті - ГОСТ) та нових, які набули чинності з 16.01.2019 p. (надалі у статті - ТУУ). За вимогами ГОСТ, лісоматеріали дуба визначали довжиною від 1,0 м 3 розподілом за якістю на три сорти ділової деревини (ГОСТ 9462-88) (Lesomaterialy kruglyye, 1988), дрова технологічні завдовжки від 2,0 м (ТУУ 56.196-95) (Derevina drov'yana, 1995), дрова паливні завдовжки від 0,3 м (ГОСТ 3243 88) (Drova, 1989). Згідно з вимогами ТУУ, розподіл виконували на лісоматеріали круглі довжиною від 1,0 м, яким встановлювали один із чотирьох класів якості (А, B, C, D) (ТУУ-00994207-003:2018) (Zbirnyk tekhnichnykh umov, 2019), деревину дров'яну промислового використання довжиною від 2,0 м і деревину дров'яну непромислового використання довжиною від 0,3 м (ТУУ00994207-005:2018) (Zbirnyk tekhnichnykh umov, 2019).

Оброблювали дані з використанням табличного процесора MS Excel, програми ПЕРТА кафедри таксації лісу та лісового менеджменту НУБіП України, а також за алгоритмами, розробленими в статистичній системі $\mathrm{R}$ ( $R$ Core Team, 2018). Основні статистики розподілу біометричних показників ділових стовбурів МД $\left(d_{1,3}-\right.$ діаметр у корі на висоті $1,3 \mathrm{~m} ; h$ - висота; $v_{c m . y \kappa}-$ об'єм стовбура в корі, м³ $v_{\text {діл. }}$ - об'єм ділової деревини, м³ $p_{\text {діл. }}$ - частка ділової деревини в об'ємі стовбура в коpi, \%) навели в табл. 1.

Табл. 1. Таксаційні показники модельних дерев та їхні статистики

\begin{tabular}{|c|c|c|c|c|c|c|c|}
\hline \multirow{3}{*}{$\begin{array}{l}\text { Статис- } \\
\text { тика }\end{array}$} & \multirow{2}{*}{\multicolumn{3}{|c|}{$\begin{array}{c}\text { Біометричний } \\
\text { показник } \\
\text { модельних дерев }\end{array}$}} & \multicolumn{4}{|c|}{$\begin{array}{c}\text { Вихід ділової деревини зі } \\
\text { стовбурів }\end{array}$} \\
\hline & & & & \multicolumn{2}{|c|}{ за ГОСТ } & \multicolumn{2}{|c|}{ за ТУУ } \\
\hline & $d_{1,3}$, & M & $v_{c m_{\text {, }}^{3 k}}$, & $v_{\partial}$ & $p_{\text {діл }}$ & $\mathrm{M}^{3}$ & \\
\hline $\bar{M}$ &, 1 & 25,8 & 1,72 & 99 & $\overline{57,2}$ & 1,07 & 61,4 \\
\hline $\max$ &, 7 & 33,5 & 98 & 73 & 75,0 & 78 & 76,3 \\
\hline $\min$ & 20,2 & 20,1 & $3 /$ & 1 & 38,0 &, 24 & 44,8 \\
\hline$\sigma$ & & 2,2 & , & $0, \supset 1$ & 8,5 & 0,54 & 6,7 \\
\hline$v, \%$ & 24,6 & 8,7 & 46,5 & 51,4 & 14,8 & 50,4 & 10,9 \\
\hline
\end{tabular}

Пояснення: " $M$ - математичне очікування; $\max$, $\min$ - максимальне та мінімальне значення; $\sigma$ - середньоквадратичне відхилення; $v$ - коефіцієнт варіації, \%.

Дослідний матеріал охоплює досить широкий діапазон мінливості біометричних показників стовбурів дерев дуба як за діаметром (20,2-65,7 cм), так і за висотою (25,8-33,5 см). Коефіцієнти варіації цих показників свідчать про однорідність дослідних даних, оскільки змінюються відповідно в діапазоні значень 20-30 \% та 8-12\% (Nikitin \& Shvidenko, 1978). За таких умов, на підставі вибірки, для регіону досліджень можливе узагальнення з певною точністю закономірностей розподілу об'єму ділових стовбурів.

3 аналізу табл. 1 помітно, що збільшення середнього значення відсотка виходу ділової деревини від 57,2\% (за ГОСТ) до 61,4 \% (за ТУУ) відбулося переважно за рахунок стовбурів з мінімальною протяжністю ділової частини. Збільшення виходу від 38,0 \% (за ГОСТ) до 44,8 \% (за ТУУ) для таких стовбурів стало наслідком переходу об'єму частини сортиментів, віднесених за ГОСТ до дров технологічних, до якісної категорії D круглих лісоматеріалів ділової деревини згідно з новими ТУУ. Ця закономірність виявлялася ще під час збирання дослідного матеріалу. Так, для стовбурів, протяжність ділової частини яких за ГОСТ сягала 15-17 м, у верхівці, відповідно до ТУУ, визначали тільки дров'яну деревину. Для стовбурів 3 меншою протяжністю ділової частини, лісоматеріали дров'яної деревини систематично були більшого діаметра, з огляду на що частину з них за ТУУ класифікували як ділову деревину.

Для виявлення кореляційних залежностей розподілу деревини ділових стовбурів на категорії залежно від діаметра, висоти та об'єму стовбурів у корі обчислили коефіцієнт кореляції Пірсона $\left(r_{y x}\right)$ (табл. 2).

Табл. 2. Кореляційна матриця залежності між біометричними показниками модельних дерев

\begin{tabular}{|c|c|c|c|c|c|c|}
\hline \multirow{3}{*}{$\begin{array}{c}\text { Залежний показ- } \\
\text { ник }^{1}\end{array}$} & \multicolumn{6}{|c|}{ Коефіцієнт кореляції $\left(r_{y x}\right)$ за показниками } \\
\hline & \multicolumn{3}{|c|}{ за ГОСТ } & \multicolumn{3}{|c|}{ за ТуУ } \\
\hline & $d_{1,3}, \mathrm{~cm}$ & $h, \mathrm{M}$ & $v_{c m . v K}, \mathrm{M}^{3}$ & $d_{1,3}, \mathrm{~cm}$ & $h, \mathrm{M}$ & $v_{c m . v \kappa}, \mathrm{M}^{3}$ \\
\hline$v_{\text {діл. }}, \mathrm{M}^{3}$ & 0,916 & 0,526 & 0,948 & 0,941 & 0,508 & 0,975 \\
\hline$p_{\text {дi... }}, \%$ & 0,080 & 0,180 & 0,089 & 0,188 & 0,177 & 0,204 \\
\hline$v_{\partial p,}, \mathrm{M}^{3}$ & 0,707 & 0,254 & 0,728 & 0,765 & 0,316 & 0,776 \\
\hline$p_{\partial p .} \%$ & $-0,161$ & $-0,104$ & $-0,152$ & $-0,108$ & $-0,011$ & $-0,116$ \\
\hline$v_{\text {sidx. }}, \mathrm{M}^{3}$ & 0,918 & 0,323 & 0,930 & 0,913 & 0,334 & 0,928 \\
\hline$p_{\text {sidx }}, \%$ & 0,226 & $-0,207$ & 0,178 & $-0,197$ & $-0,367$ & $-0,216$ \\
\hline
\end{tabular}

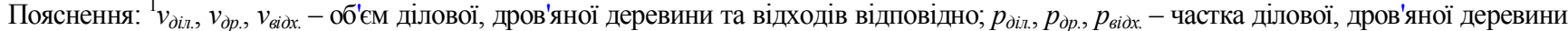
та відходів від об'єму стовбура в корі відповідно.

За кількості спостережень $n=102$ та рівня значущості $\alpha=0,05$ критичне значення коефіцієнта кореляції становить $r_{\kappa p}=0,195$ (Nikitin \& Shvidenko, 1978). Таким чином, фактичні значення коефіцієнтів кореляції між відсотками ділової $\left(p_{\text {діл. }}\right)$ та дров'яної $\left(p_{\text {др. }}\right)$ деревини і біометричними показниками стовбурів менші за критич- не значення або наближуються до нього (див. табл. 2). Це свідчить про відсутність лінійної залежності між цими показниками. Для абсолютних значень об'єму цих категорій деревини виявили тісну лінійну залежність від об'єму стовбура в корі. Для порівняння на рис. 1 зображено залежність виходу ділової деревини 
від діаметра та об'єму стовбура в корі, встановлену за вимогами ТУУ у відносних та абсолютних значеннях.
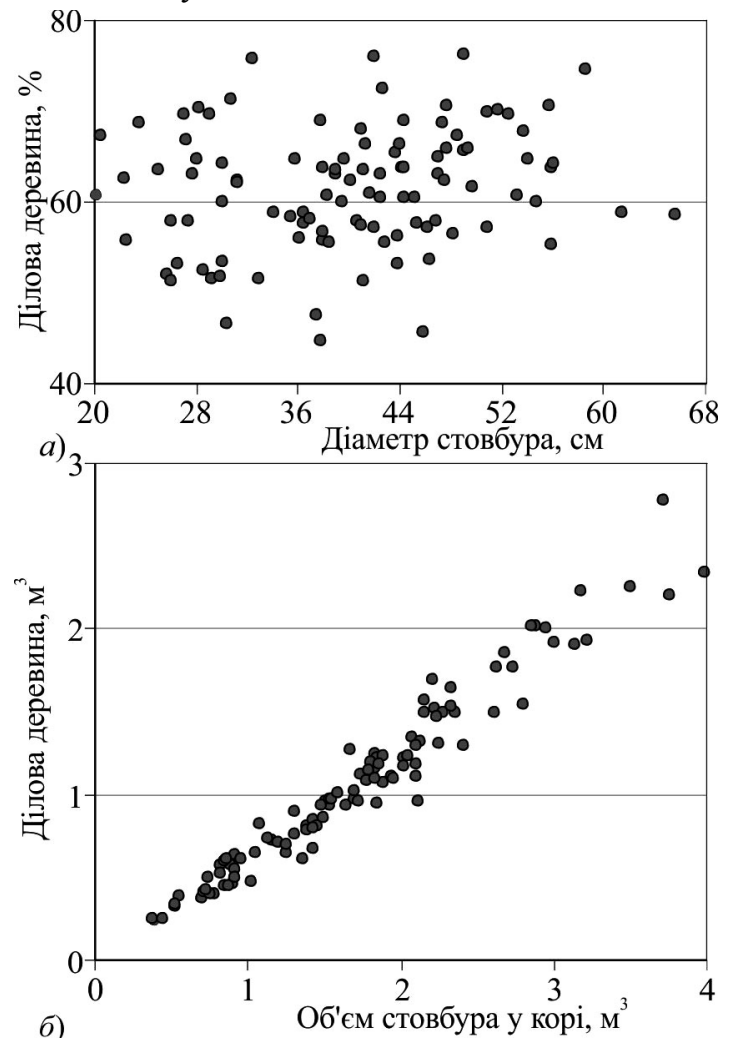

Рис. 1. Вихід ділової деревини: а) у відносних показниках залежно від діаметра стовбура; б) в абсолютних показниках залежно від об'єму стовбура

Очевидно, що математичні моделі, розроблені для залежностей виходу категорій деревини в абсолютних величинах від об'єму стовбура в корі, матимуть вищу точність, адже вони враховують вплив на ці показники не тільки діаметра, а й висоти та форми стовбура, про що свідчать дані табл. 2. Залежність виходу ділової та дров'яної деревини від об'єму стовбура досить вдало описує степеневе рівняння (1), а відходів - очевидно, рівняння (2):

$$
\begin{gathered}
v_{\text {діл. }(\partial p .)}=a_{0} \cdot v_{c m . y \kappa}^{a_{1}}+a_{2} ; \\
v_{\text {вidx. }}=v_{c m . y \kappa}-v_{\partial i л .}-v_{\partial p .},
\end{gathered}
$$

де $v_{c m . y \kappa}, v_{\partial і л .}, v_{\partial p .}, v_{\text {вiдx. }}-$ об'єми стовбура в корі, ділової, дров'яної деревини та відходів відповідно.

Обчислення параметрів рівняння (1) виконано в MS Excel та наведено в табл. 3.

Табл. 3. Параметри математичної моделі виходу ділової та дров'яної деревини

\begin{tabular}{|c|c|c|c|c|}
\hline \multirow{2}{*}{ Параметр } & \multicolumn{2}{|c|}{ За ГОСТ } & \multicolumn{2}{c|}{ За ТУУ } \\
\cline { 2 - 5 } & ділова & дров'яна & ділова & дров'яна \\
\hline$a_{0}$ & 0,5290 & 0,4298 & 0,5714 & 0,3672 \\
\hline$a_{1}$ & 1,091 & 0,5941 & 1,089 & 0,5271 \\
\hline$a_{2}$ & 0,02069 & $-0,1678$ & 0,2526 & $-0,1707$ \\
\hline
\end{tabular}

Примітка. Область визначення рівнянь: $0,37 \leq v_{c m . y \kappa} \leq 4,0$.

Прогнозні значення об'єму досліджуваних категорій деревини за математичними моделями (1) і (2) на фоні дослідних даних зображено на рис. 2.

Для отримання даних розподілу ділової за класами розмірів, передбачених ДСТУ 1315-1-2011 (за серединним діаметром), розробили алгоритм умовного розкряжування модельних дерев та реалізували його у системі $\mathrm{R}$.
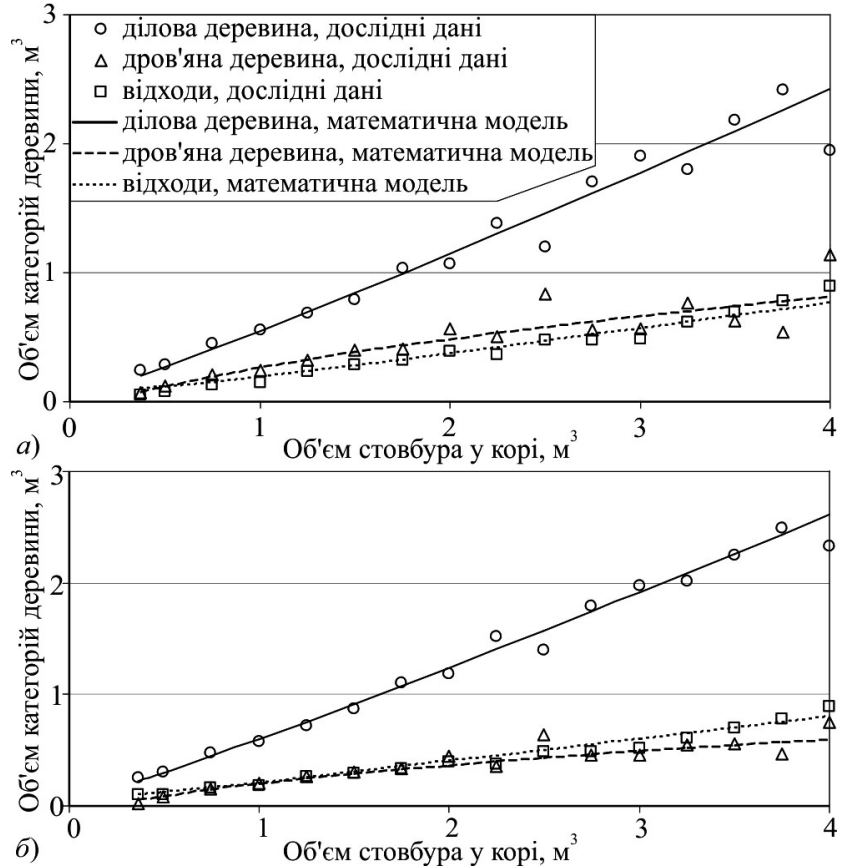

Рис. 2. Розподіл об'єму стовбура в корі на категорії (маркерами зображено згруповані середні значення категорій деревини за об'ємом стовбура, з градацією $0,25 \mathrm{~m}^{3}$ ): а) сортиментація за ГОСТ; б) сортиментація за ТУУ

Його побудовано на апроксимації твірної поверхні стовбура за допомогою математичної моделі A. Kozak (1988), яку було опрацьовано на цьому ж дослідному матеріалі (Bуchenko \& Myroniuk, 2019). Зміст алгоритму полягає у такому:

1. Формування вихідних наборів даних. За результатами обміру зрубаних стовбурів визначаються показники модельних дерев: діаметр; висота; послідовність зон стовбура відповідних класів якості та їхні довжини. Окремо задаються паспорти сортиментів: мінімальні та максимальні довжини лісоматеріалів за класами якості A, В, C, D ділової деревини, дров промислового і непромислового використання; діаметри лісоматеріалів; градація за довжиною та діаметром (серединним без кори - для ділових лісоматеріалів, верхнім у корідров'яних). Сортименти розміщуються за пріоритетом від вищого (клас якості А) до нижчого (дрова непромислового використання).

2. Моделювання збігу та обчислення об'єму якісних категорій стовбурів. Алгоритм будує твірну стовбура в корі і без кори. Послідовно, від окоренка до верхівки стовбура, проаналізували кожну якісну зону стовбура, порівнюючи іï з вимогами паспорта сортиментів відповідного класу якості згідно зі спаданням пріоритетів. Якщо серединний діаметр та/або мінімальна довжина зони стовбура не задовольняють вимоги паспорта, то відбувається перехід до наступного сортименту. Якщо у паспорті встановлено обмеження за максимальною довжиною, то аналізуємо можливість одержання в зоні додаткового сортименту цього ж класу якості, інакше залишковий відрізок приписується до наступної зони. Остання умова стосується тільки ділової деревини, проте якщо за відрізком ділової деревини розташовується дров'яна, то визначається можливість одержання сортименту ділової деревини нижчого класу якості й тільки після цього відрізок приписується до наступної зони. Таким чином порівнюються всі зони стовбура від окоренка до верхівки з фіксацією точок умовного розкряжування. Далі за твірною стовбура визначаються серединні діаметри без кори ділових сортиментів і вер- 
хні діаметри в корі для дров промислового та непромислового використання. На підставі секційної формули Сімпсона (за довжини секції 1/100 довжини сортименту) обчислюється об'єм без кори для ділових, або 3 корою - для дров'яних сортиментів.

3. Агрегація даних за класами якості та розмірів. Зведені дані містять інформацію про параметри кожного сортименту, отриманого з конкретного модельного дерева: серединний діаметр без кори для ділових сортиментів та верхній з корою - для дров, довжину та об'єм.

На підставі отриманих даних розмірної структури за класами діаметрів проведено графічний аналіз форми їх залежності від біометричних показників стовбурів дерев дуба. Практично у всіх випадках виявився нелінійний зв'язок. Узагальнення розмірної структури ділової деревини провели за методикою, яку було використано під час розроблення чинних сортиментних таблиць (Kashpor \& Strochynskyi, 2013). Зазначену методику започаткували К. Є. Нікітін та А. 3. Швиденко (Nikitin \& Shvidenko, 1972). Вона базується на дослідженні закономірностей розподілу об'єму ділової деревини за класами розмірів у відносних величинах. Провівши дослідження залежності відносних показників розмірної структури від інших таксаційних показників стовбурів, виявили тісну залежність від діаметра на висоті 1,3 м. Пошук форми залежностей та обчислення параметрів рівнянь (3)-(7) виконали в MS Excel:

$$
\begin{aligned}
& p_{15-19}=\left\{\begin{array}{ll}
100, & d=20 \\
303215 \cdot \exp (-0,3556 \cdot d)-1,064, & 20<d \leq 32
\end{array},\right. \\
& p_{20-29}= \begin{cases}100-p_{15-19^{\prime}} & 24 \leq d \leq 28 \\
0,000364(d-10,19)^{9,820} & \exp (-0,557 d), 28<d \leq 52\end{cases} \\
& p_{30-39}= \begin{cases}100-p_{15-19}-p_{20-29}, & 32 \leq d \leq 36 \\
0,000122(d-18,11)^{9,434} \exp (-0,3943 d), & 36<d \leq 64\end{cases} \\
& p_{40-49}=100-p_{20-29}-p_{30-39}-p_{50-59}, 40 \leq d \leq 64, \\
& p_{50-59}=21,07 \cdot(d-51,02)^{1,193} \cdot \exp (-0,0380 \cdot d), 52<d \leq 64,(7)
\end{aligned}
$$

де: $d$ - діаметр стовбура на висоті $1,3 \mathrm{M}, p_{15-19}, p_{20-29}, p_{30-}$ $39, p_{40-49}, p_{50-59}$ - відсоток об'єму ділової деревини відповідного класу розмірів від загального об'єму ділової деревини у стовбурі (в індексі зазначено серединні діаметри без кори, см).

Апроксимацію дослідних даних знайденими залежностями (3)-(7) представлено на рис. 3.

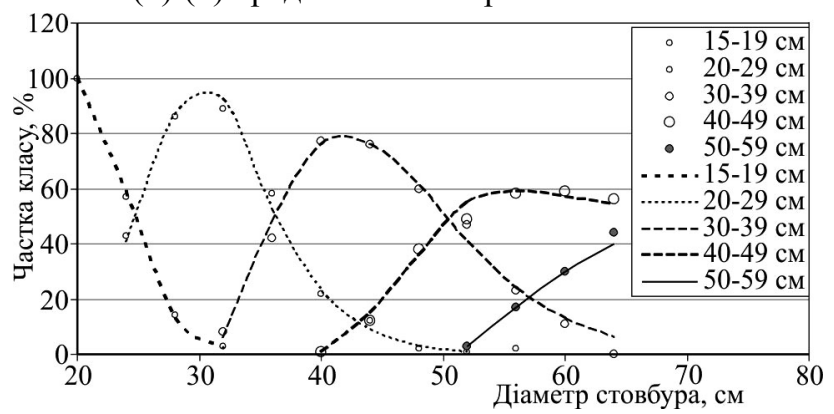

Рис. 3. Розподіл ділової деревини за класами розмірів залежно від діаметра стовбура (маркерами зображено дослідні дані, згруповані за ступенями товщини, а лініями - відповідні математичні моделі)

Для оцінки точності розроблених кореляційних моделей використали такі статистики:

- систематична похибка:

$$
u=\frac{1}{n} \cdot \sum_{i=1}^{n}\left(\hat{y}_{i}-y_{i}\right)
$$

- систематична відносна похибка:

$$
u \%=\frac{1}{n} \cdot \sum_{i=1}^{n} \frac{\hat{y}_{i}-y_{i}}{y_{i}} \cdot 100 \%
$$

• абсолютна похибка:

$$
|u|=\frac{1}{n} \cdot \sum_{i=1}^{n}\left|\hat{y}_{i}-y_{i}\right|
$$

- стандартна похибка моделювання:

$$
s=\sqrt{\frac{\sum_{i=1}^{n}\left(\hat{y}_{i}-y_{i}\right)^{2}}{n-k-1}} ;
$$

• коефіцієнт детермінації:

$$
r_{x y}^{2}=1-\frac{\sum_{i=1}^{n}\left(\hat{y}_{i}-y_{i}\right)^{2}}{\sum_{i=1}^{n}\left(y_{i}-\bar{y}\right)^{2}},
$$

де: $y_{i}$ - фактичне значення показника, $\hat{y}_{i}$ - розрахункове значення показника, $\bar{y}-$ середнє фактичне значення показника, $n$ - кількість спостережень, $k$ - кількість незалежних змінних у математичній моделі.

Обчислені статистики за рівняннями (8)-(12) для моделей розподілу об'єму стовбура на ділову, дров'яну деревину та відходи (1) і (2) навели в табл. 4.

Табл. 4. Точність математичних моделей розподілу об'єму стовбурів дерев дуба на якісні категорії

\begin{tabular}{|c|c|c|c|c|c|c|}
\hline \multirow{2}{*}{$\begin{array}{c}\text { Статис- } \\
\text { тика }\end{array}$} & \multicolumn{5}{|c|}{ Значення статистик за стандартами та якісними ка- } \\
\cline { 2 - 7 } & \multicolumn{3}{|c|}{ за ГОСТ } & \multicolumn{3}{c|}{ за ТУУ } \\
\cline { 2 - 7 } & ділова & дров'яна & відходи & ділова & дров'яна & відходи \\
\hline$u, \mathrm{M}^{3}$ & $-0,002$ & $-0,007$ & 0,009 & 0,000 & $-0,018$ & 0,018 \\
\hline$u, \%$ & 1,3 & 9,9 & 9,9 & 1,0 & 5,1 & 8,0 \\
\hline$|u|, \mathrm{m}^{3}$ & 0,122 & 0,113 & 0,046 & 0,089 & 0,074 & 0,045 \\
\hline$s, \mathrm{M}^{3}$ & 0,161 & 0,151 & 0,063 & 0,118 & 0,100 & 0,063 \\
\hline$r_{x y}^{2}$ & 0,898 & 0,529 & 0,861 & 0,952 & 0,611 & 0,849 \\
\hline
\end{tabular}

Аналізуючи дані табл. 4, помітно дещо високі значення систематичної відносної похибки $(u \%)$ для дров'яної деревини за ГОСТ та відходів у обох випадках. Причиною цього може бути значна мінливість діаметрів у верхівці стовбура $\mathrm{i}$, як наслідок, мінливість об'ємів цих категорій деревини. Коефіцієнти детермінації $\left(r_{x y}^{2}\right)$ для цих категорій також нижчі, ніж для ділової деревини, тобто частка непоясненої дисперсії вища. Але загалом можна відзначити, що математичні моделі 3 прийнятною точністю апроксимують залежності, адже їх систематична похибка близька до нуля. Значущим $є$ i коефіцієнт детермінації - для усіх рівнянь він більший за критичний $\left(r_{\kappa p}{ }^{2}=0,038\right.$ при $\left.\alpha=0,05\right)$.

Для моделей розподілу об'єму ділової деревини на класи розмірів (3)-(7), показники точності за рівняннями (8) та (10)-(12) навели в табл. 5.

Табл. 5. Точність математичних моделей розподілу об'єму ділової деревини за класами розмірів

\begin{tabular}{|c|c|c|c|c|c|}
\hline $\begin{array}{c}\text { Ста- } \\
\text { тисти- } \\
\text { ка }\end{array}$ & \multicolumn{4}{|c|}{ Значення статистик за класами розмірів } \\
\cline { 2 - 6 } & $15-19$ & $20-29$ & $30-39$ & $40-49$ & $50-59$ \\
\hline$u, \%$ & 0,0 & $-1,1$ & 0,7 & 0,9 & 0,1 \\
\hline$|u|, \%$ & 8,8 & 9,1 & 10,8 & 8,8 & 7,3 \\
\hline$s, \%$ & 11,1 & 12,0 & 13,6 & 12,0 & 9,0 \\
\hline$r_{x v}^{2}{ }^{2}$ & 0,866 & 0,886 & 0,768 & 0,755 & 0,638 \\
\hline$r_{k p .}{ }^{2}$ & 0,122 & 0,038 & 0,047 & 0,063 & 0,219 \\
\hline
\end{tabular}

Аналізуючи статистики в табл. 5, необхідно відзначити дещо зависокі значення стандартної похибки моделювання $(s)$, які спричинені, очевидно, мінливістю протяжності ділової деревини по стовбуру. Адекватність розроблених моделей підтверджує графічний аналіз (див. рис. 3) (лінія рівняння проходить близько до середніх значень фактичних даних), невисоке значення 
систематичної похибки (змінюється у межах від $-1,1 \%$ до $0,9 \%$ ) та значущість коефіцієнта детермінації $\left(r_{x y}^{2}\right)$, який більший за критичний $\left(r_{\kappa p}{ }^{2}\right)$ при $\alpha=0,05$, для усіх класів розмірів.

На підставі розроблених математичних моделей (1)(7) склали таблиці розподілу об'єму ділових стовбурів дуба (табл. 6) та розподілу ділової деревини ділових стовбурів дуба за класами розмірів за серединним діаметром без кори (табл. 7). Ці таблиці дають можливість у виробничих умовах з достатньою точністю прогнозувати вихід ділової деревини за новими стандартами та здійснювати іiі розподіл за класами розмірів.

Табл. 6. Розподіл об'єму ділових стовбурів дуба, \%

\begin{tabular}{|c|c|c|c|c|c|c|c|c|c|}
\hline \multirow{2}{*}{$\begin{array}{c}\text { Об'єм стов- } \\
\text { бура в корі, } \\
\mathrm{m}^{3}\end{array}$} & \multicolumn{3}{|c|}{ За ГОСТ } & \multicolumn{3}{|c|}{ За ДСТУ } & \multicolumn{3}{|c|}{ Різниця } \\
\hline & ділова & дров'яна & відходи & ділова & дров'яна & відходи & ділова & дров'яна & відходи \\
\hline 0,37 & 53,9 & 18,4 & 27,7 & 59,1 & 12,7 & 28,2 & 5,2 & $-5,7$ & 0,5 \\
\hline 0,50 & 53,8 & 22,8 & 23,4 & 58,8 & 16,8 & 24,4 & 5,0 & $-6,0$ & 1,0 \\
\hline 0,75 & 54,3 & 25,5 & 20,2 & 59,1 & 19,3 & 21,6 & 4,8 & $-6,2$ & 1,4 \\
\hline 1,00 & 55,0 & 25,7 & 19,3 & 59,7 & 19,6 & 20,7 & 4,7 & $-6,1$ & 1,4 \\
\hline 1,25 & 55,7 & 25,4 & 18,9 & 60,3 & 19,4 & 20,3 & 4,6 & $-6,0$ & 1,4 \\
\hline 1,50 & 56,3 & 24,9 & 18,8 & 60,9 & 18,9 & 20,2 & 4,6 & $-6,0$ & 1,4 \\
\hline 1,75 & 56,9 & 24,3 & 18,8 & 61,5 & 18,4 & 20,1 & 4,6 & $-5,9$ & 1,3 \\
\hline 2,00 & 57,4 & 23,7 & 18,9 & 62,1 & 17,9 & 20,0 & 4,7 & $-5,8$ & 1,1 \\
\hline 2,25 & 57,9 & 23,1 & 19,0 & 62,5 & 17,4 & 20,1 & 4,6 & $-5,7$ & 1,1 \\
\hline 2,50 & 58,3 & 22,6 & 19,1 & 63,0 & 17,0 & 20,0 & 4,7 & $-5,6$ & 0,9 \\
\hline 2,75 & 58,8 & 22,1 & 19,1 & 63,5 & 16,5 & 20,0 & 4,7 & $-5,6$ & 0,9 \\
\hline 3,00 & 59,2 & 21,6 & 19,2 & 63,9 & 16,1 & 20,0 & 4,7 & $-5,5$ & 0,8 \\
\hline 3,25 & 59,5 & 21,2 & 19,3 & 64,2 & 15,8 & 20,0 & 4,7 & $-5,4$ & 0,7 \\
\hline 3,50 & 59,9 & 20,8 & 19,3 & 64,6 & 15,4 & 20,0 & 4,7 & $-5,4$ & 0,7 \\
\hline 3,75 & 60,2 & 20,4 & 19,4 & 65,0 & 15,1 & 19,9 & 4,8 & $-5,3$ & 0,5 \\
\hline 4,00 & 60,6 & 20,0 & 19,4 & 65,3 & 14,8 & 19,9 & 4,7 & $-5,2$ & 0,5 \\
\hline
\end{tabular}

Табл. 7. Розподіл об'сму ділової деревини стовбурів дуба за серединним діаметром сортиментів без кори, \%

\begin{tabular}{|c|c|c|c|c|c|c|c|c|c|c|}
\hline \multirow{2}{*}{$\begin{array}{c}\text { Діаметр стов- } \\
\text { бура, см }\end{array}$} & \multicolumn{8}{|c|}{ Серединний діаметр сортиментів без кори, см } \\
\cline { 2 - 11 } & $15-19$ & $20-29$ & $30-39$ & $40-49$ & $50-59$ & $15-19$ & $20-29$ & $30-39$ & $40-49$ & $50-59$ \\
\hline 20 & 100 & - & - & - & - & 100 & - & - & - & - \\
\hline 24 & 57 & 43 & - & - & - & 59 & 41 & - & - & - \\
\hline 28 & 14 & 86 & - & - & - & 13 & 87 & - & - & - \\
\hline 32 & 3 & 89 & 8 & - & - & 2 & 92 & 6 & - & - \\
\hline 36 & - & 58 & 42 & - & - & - & 52 & 48 & - & - \\
\hline 40 & - & 22 & 77 & 1 & - & - & 23 & 76 & 1 & - \\
\hline 44 & - & 12 & 76 & 12 & - & - & 9 & 76 & 15 & - \\
\hline 48 & - & 2 & 60 & 38 & - & - & 3 & 61 & 36 & - \\
\hline 52 & - & 1 & 47 & 49 & 3 & - & 1 & 41 & 55 & 3 \\
\hline 56 & - & 2 & 23 & 58 & 17 & - & - & 24 & 59 & 17 \\
\hline 60 & - & - & 11 & 59 & 30 & - & - & 13 & 57 & 30 \\
\hline 64 & - & - & - & 56 & 44 & - & - & 6 & 54 & 40 \\
\hline
\end{tabular}

Обговорення результатів дослідження. Аналізуючи відсоток виходу ділової деревини за ГОСТ (див. табл. 6), помітні дещо нижчі його значення, ніж у чинних нормативах. Так, за "Лісотаксаційним довідником" (Kashpor \& Strochynskyi, 2013) для стовбурів діаметром $\geq 32$ см вихід ділової деревини становить $72 \%$. За нашими дослідженнями для регіону вихід становить від $54,3 \%$ (стовбур об'ємом $0,75 \mathrm{~m}^{3}$ ), до 60,6 \% (стовбур об'ємом 4,0 м³). Хоча в дослідному матеріалі наявні стовбури з високою часткою ділової деревини до 75 \% (див. табл. 1), вирівняні дані свідчать про особливість розподілу об'єму стовбурів дуба за якісними категоріями для регіону досліджень.

Варто зауважити, що зазначені таблиці стосуються тільки ділових стовбурів. Як зазначалось вище, із переходом України на стандарти визначення якості лісоматеріалів, гармонізовані з європейськими вимогами, чинна методика (Metodychni vkazivky, 2013) розподілу стовбурів за категоріями технічної придатності (ділові, напівділові та дров'яні) де-факто втратила зміст. За новими стандартами у більшості напівділових та дров'яних стовбурів за рахунок частини сортиментів, які класифікували за ТУУ як "технологічна сировина для виробничо-технічного призначення", збільшується протяжність ділової частини (категорії D). Внаслідок цього такі стовбури переходять у категорії ділових та/або напівді- лових відповідно. Тобто загальне зростання ділової деревини на певній лісосіці спричинене збільшенням іiі виходу зі стовбурів усіх категорій. Очевидно, що закономірності виходу ділової деревини з напівділових та дров'яних стовбурів потребують додаткових досліджень.

Висновки. За проведеними дослідженнями можна зробити декілька основних висновків:

1. Найбільш тісну лінійну залежність простежуємо для абсолютних значень об'ємів якісних категорій деревини від об'єму стовбура в корі. Така залежність враховує вплив на вихід ділової деревини, дров та відходів не тільки діаметра, а й висоти стовбура.

2. Відносні значення показників розмірної структури ділової деревини найбільш тісно корелюють 3 діаметром стовбура. Форма цієї залежності нелінійна, досить складна та апроксимується переважно системою рівнянь.

3. Розроблені таблиці розподілу дають змогу для дубових насаджень Придніпровського Правобережного Лісостепу з достатньою точністю прогнозувати вихід ділової деревини за новими європейськими стандартами та здійснювати іiї розподіл на класи розмірів. 


\section{Перелік використаних джерел}

Bychenko, V. B., \& Myroniuk, V. V. (2019). Some peculiarities of stem taper modelling of common oak trees. Scientific Bulletin of UNFU, 29(5), 69-74. https://doi.org/10.15421/40290514

DSTU 4020-2-2001 (pr EN 1309-2: 1998). (2001). Roundwood timber and sawnwood. Principles of scaling, from 05 April 2001. (Part 2). Kiev: Derzhstandart Ukrainy. [In Ukrainian].

DSTU EN 1315-1:2001 (EN 1315-1:1997, IDT). (2002). Roundwood timber of deciduous species. Classification by sizes, from 01 Jan 2003. (Part 1). Kiev: Derzhstandart Ukrainy. [In Ukrainian].

Forest Resources. (2013). Guidelines for pre-harvest survey and assessment, obtaining permissions for harvesting and inspection of harvested areas in forests of the State Forest Resources Agency of Ukraine, from 21 Jan 2013. [In Ukrainian].

GOST 2708-75. (1975). Roundwood timbers. Volume tables, from 01 Jan 1977. Moscow: IPK Publishing House Standartov. [In Russian].
GOST 3243-88. (1989). Firewood. Technical specifications, from 01 Jan 1990. Moscow: Publishing House Standartov. [In Russian].

GOST 9462-88. (1988). Roundwood timber of deciduous species. Technical specifications, from 01 Jan 1990. Moscow: Publishing House Standartov. [In Russian].

Kashpor, S. M., \& Strochynskyi, A. A. (2013). Forest inventory handbook. Kiev: Vinichenko. [In Ukrainian].

Nikitin, K. E., \& Shvidenko, A. Z. (1978). Methods and technique of data processing in forestry. Moscow: Lesnaja Promyshlennost. [In Russian].

Nikitin, K. E., \& Shvidenko, A. Z. (1972). Pre-harvest assessment of forest stands using computers. Kiev: Urozhay. [In Russian].

Getting Started. (2018). The R Project for Statistical Computing. Retrieved from: https://www.r-project.org/

Roundwood Grading. (2019). Compilation of technical specifications on roundwood grading. Kiev: State Enterprise "Forestry Innovative and Analytical Center". [In Ukrainian].

TUU 56.196-95. (1995). Derevina drovyana dlya tekhnologichnikh potreb, from 26 Jan 1995. Kiev: Standarty. [In Ukrainian].

V. B. Bychenko

National University of Life and Environmental Sciences of Ukraine, Kyiv,Ukraine

MODELING OF SIZE AND QUALITY STRUCTURE OF COMMON OAK TREE STEM IN COMPLIANCE WITH EUROPEAN STANDARDS

The paper highlights some of the issues related to adopting in Ukraine novel standards on roundwood timber. Inconsistency of the reference data relevant to pre-harvest assessment of forest stands harmonized with new standards results in a significant drawback in planning of production activities by state forest enterprises. The study is based on empirical data collected on temporary sample plots established in Common oak stands of Dnieper Right-bank Forest-Steppe of Ukraine. We have investigated the distribution of stem volume of merchantable trees of Common oak (Quercus robur L.) by wood quality categories depending on tree stem diameter, height and volume. The strictest linear relationship has been revealed for absolute values of wood quality categories and stem volume outside bark. The linear relationship between other biometrical parameters of stems has not been set or it was less significant at $5 \%$ significance level. The performed analysis has allowed predicting the distribution of wood quality classes depending on tree stem volume outside bark using power function. The parameters of the model have been fitted in MS Excel. Systematic error of mathematical models of merchantable wood volume distribution was close to zero $(1.0 \%)$, for firewood and residuals it was in reasonable ranges $(5.1$ and $8.0 \%$ ) that allowed applying the models to develop volume tables. The developed tables predict the distribution of volume of merchantable oak trees using new standards and have negligible standard error of $0.063-0.118 \mathrm{~m}^{3}$. We have developed an algorithm of conditional cross cutting of sample trees into timbers in the $\mathrm{R}$ statistical computing environment to retrieve the distribution of merchantable wood volume by diameter classes of the State standard of Ukraine DSTU 1315-1-2011. The algorithm is based on predicting stem taper using A. Kozak (1988) function. Based on predicted distribution of merchantable wood volume by diameter classes we have investigated its relationship with biometrical parameters of tree stems. Nearly for all wood size classes nonlinear relationship has been found. We used a methodology considering the analysis of the specifics of wood volume distribution by size classes in relative values to describe quantitative parameters of merchantable wood volume. As a result, strict relationship of relative values of wood volumes of the specific size classes has been found depending on diameter at $1.3 \mathrm{~m}$ of model trees. The insignificant systematic error of the mathematical models of merchantable wood volume distribution $(-1.1-0.9 \%)$ allowed us to use them in volume tables construction. These tables are harmonized with new standard and predict the distribution of merchantable wood volume of merchantable stems of oak trees by size classes depending on middle-point diameters of logs inside bark.

Keywords: standards on roundwood timber; stem quality categories; distribution of stem volume by quality and size classes; mathematical models of wood volume distribution. 